\title{
The Cpx two-component signal transduction pathway of Escherichia coli regulates transcription of the gene specifying the stress-inducible periplasmic protease, DegP
}

\author{
Paul N. Danese, William B. Snyder, Christine L. Cosma, Laura J.B. Davis, ${ }^{1}$ and Thomas J. Silhavy ${ }^{2}$ \\ Department of Molecular Biology, Princeton University, Princeton, New Jersey 08544 USA
}

\begin{abstract}
DegP is a heat-shock inducible periplasmic protease in Escherichia coli. Unlike the cytoplasmic heat shock proteins, DegP is not transcriptionally regulated by the classical heat shock regulon coordinated by $\sigma^{32}$. Rather, the $\operatorname{deg} P$ gene is transcriptionally regulated by an alternate heat shock $\sigma$ factor, $\sigma^{\mathrm{E}}$. Previous studies have demonstrated a signal transduction pathway that monitors the amount of outer-membrane proteins in the bacterial envelope and modulates $\operatorname{deg} P$ levels in response to this extracytoplasmic parameter. To analyze the transcriptional regulation of $\operatorname{deg} P$, we examined mutations that altered transcription of a $\operatorname{deg} P-\operatorname{lacZ}$ operon fusion. Gain-of-function mutations in $\operatorname{cpx} A$, which specifies a two-component sensor protein, stimulate transcription from $\operatorname{deg} P$. Defined null mutations in $\operatorname{cpx} A$ or the gene encoding its cognate response regulator, $\operatorname{cpx} R$, decrease transcription from $\operatorname{deg} P$. These null mutations also prevent transcriptional induction of $\operatorname{deg} P$ in response to overexpression of a gene specifying an envelope lipoprotein. Cpx-mediated transcription of $\operatorname{deg} P$ is partially dependent on the activity of $\mathrm{E \sigma}^{\mathrm{E}}$, suggesting that the $\mathrm{Cpx}$ pathway functions in concert with $E \sigma^{E}$ and perhaps other RNA polymerases to drive transcription of $\operatorname{deg} P$.
\end{abstract}

[Key Words: Heat shock; $\sigma^{\mathrm{E}}$; receptor kinase; lipoprotein; response regulator]

Received November 23, 1994; revised version accepted January 12, 1995.

The heat shock, or stress, proteins are a ubiquitous set of proteins whose synthesis is induced in response to environmental insults such as abrupt temperature elevation. It is thought that during times of stress these proteins maintain viability of the cell by degrading proteins that have been irreversibly inactivated and by promoting the renaturation/activation of reversibly inactivated proteins. Thus, heat shock proteins are often proteases or molecular chaperones (Gething and Sambrook 1992; Bukau 1993; Craig et al. 1993). Although heat shock proteins are required during times of stress, many of them also perform important functions in unstressed cells. For example, in Escherichia coli the molecular chaperones are thought to assist in protein folding (Zeilstra-Ryalls et al. 1991; Gething and Sambrook 1992), whereas proteases such as Lon serve post-translational regulatory roles (Gottesman 1989; Goldberg 1992).

Because heat shock proteins perform such fundamental functions, it is not surprising that they are found in a variety of subcellular compartments in both prokaryotic

\footnotetext{
${ }^{1}$ Present address: University of Texas Southwestern Medical School, Dallas, Texas 75235-9096 USA.

${ }^{2}$ Corresponding author.
}

and eukaryotic cells (Deshaies et al. 1988; Strauch and Beckwith 1988; Craig et al. 1989; Rose et al. 1989). Interestingly, the regulation of stress proteins found in one compartment is often coordinated independently of stress proteins within other compartments (Strauch and Beckwith 1988; Strauch et al. 1989; Mori et al. 1993). For example, stresses that specifically perturb the bacterial envelope in $E$. coli increase the synthesis of the periplasmic protease DegP (Lipinska et al. 1990), whereas the synthesis of cytoplasmic stress proteins remains unaffected (Mecsas et al. 1993). Consistent with this observation, the $\operatorname{deg} P$ locus is not transcriptionally regulated by the classical heat shock $\sigma$ factor, $\sigma^{32}$. Rather, its transcription is directed by a second heat shock $\sigma$ factor, $\sigma^{\mathrm{E}}$ (also known as $\sigma^{24}$ ) (Lipinska et al. 1988; Erickson and Gross 1989; Wang and Kaguni 1989). Like $\sigma^{32}, \sigma^{\mathrm{E}}$ is thought to direct transcription of a stress regulon $(\mathrm{Mec}-$ sas et al. 1993). Specifically, RNA polymerase (E) containing $\sigma^{\mathrm{E}}\left\langle\mathrm{E} \sigma^{\mathrm{E}}\right)$ is thought to be specifically involved in coordinating responses to extracytoplasmic stresses. Mecsas and colleagues (1993) have shown that the activity of $E \sigma^{E}$ is modulated in response to the synthesis of outer-membrane proteins. High-level synthesis of a wide array of outer-membrane proteins increases E $\sigma^{\mathrm{E}}$ activity, 
and, hence, DegP synthesis. Conversely, mutations that decrease the number of proteins found in the outermembrane concomitantly decrease $E \sigma^{\mathrm{E}}$ activity. Thus, $\sigma^{\mathrm{E}}$ responds to a general extracytoplasmic parameter, just as $\sigma^{32}$ responds to general conditions known to damage cytoplasmic proteins (Bukau 1993).

If $\sigma^{\mathrm{E}}$ does serve a complementary function to that of $\sigma^{32}$, it is likely that E $\sigma^{\mathrm{E}}$ directs transcription of various envelope stress proteins in response to alterations in the physiology of the bacterial envelope. To examine this intercompartmental communication, we analyzed mutations that affected transcription of $\operatorname{deg} P$. Using a $\operatorname{deg} P$ $l a c Z$ operon fusion we have identified a two-component regulatory system (Stock et al. 1990) that is involved in transcriptional regulation of $\operatorname{deg} P$.

\section{Results}

The degP-lacZ operon fusion accurately reflects $\operatorname{degP}$ transcription

A $\operatorname{deg} P-1 a c Z$ operon fusion was constructed to study the transcriptional regulation of the $\operatorname{deg} P$ locus in $E$. coli. The fusion was recombined onto a $\lambda$ phage and was placed in single copy at the attB locus on the $E$. coli chromosome (see Materials and methods for details). Like the wild-type $\operatorname{deg} P$ locus, transcription from this fusion is altered by genetic backgrounds that alter the activity of $\mathrm{E \sigma}^{\mathrm{E}}$, the RNA polymerase responsible for transcriptional initiation at the $\operatorname{deg} P$ locus (Erickson and Gross 1989; Wang and Kaguni 1989|. E $\sigma^{\mathrm{E}}$ activity is modulated in response to the synthesis of outer-membrane proteins. For example, high-level synthesis of outermembrane proteins such as OmpF or OmpC increases $E \sigma^{E}$ activity. Conversely, mutations that decrease the number of proteins found in the outer membrane decrease $E \sigma^{\mathrm{E}}$ activity (Mecsas et al. 1993). Figure 1 shows that high-level synthesis of the outer-membrane proteins OmpF or OmpC stimulates transcription of the $\operatorname{deg} P-l a c Z$ fusion. In contrast, the ompR::Tn10 mutation, which decreases $E \sigma^{\mathrm{E}}$ activity by eliminating expression of ompF and ompC (Slauch et al. 1988), decreases transcription from the $\operatorname{deg} P-l a c Z$ fusion (Fig. 1). Thus, the $\operatorname{deg} P-1 a c Z$ fusion is an accurate reporter of transcription at the $\operatorname{deg} P$ locus.

\section{Mutations in cpxA stimulate transcription of $\operatorname{deg} \mathrm{P}$}

To identify genes involved in transcriptional regulation of $\operatorname{deg} P$, we sought mutations that altered transcription of the $\operatorname{deg} P-1 a c Z$ fusion. Our first candidate for such a gene arose from concurrent studies of two novel envelope proteins in our laboratory. The LamB-LacZ-PhoA fusion protein (Snyder and Silhavy 1995) and the signalsequence processing-defective maltoporin, LamBA23D (Carlson and Silhavy 1993), are both targeted to the bacterial envelope and both damage the envelope when their genes are highly expressed. Such high-level synthesis of LamB-LacZ-PhoA causes cell lysis because of an undefined perturbation in the bacterial envelope /Snyder and

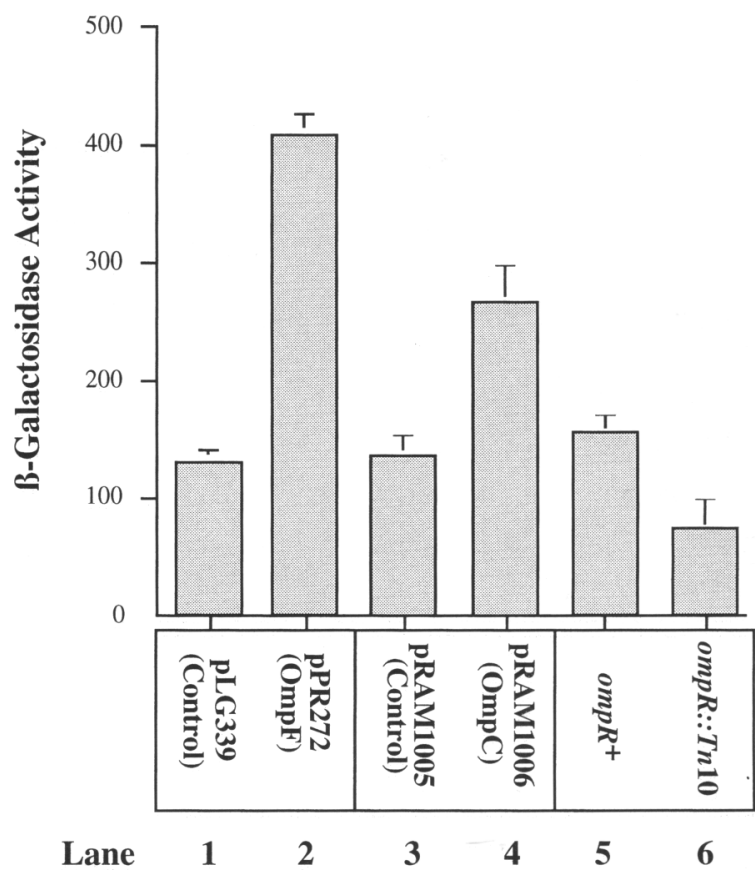

Figure 1. Transcription of a $\operatorname{deg} P-\operatorname{lac} Z$ fusion is modulated in response to outer-membrane protein levels. Lanes 1-4 display the $\beta$-galactosidase activities of PND2000 (MC4100, $\lambda$ RS88[degP-lacZ]) transformed with pLG339 (control for pPR272) (lane 1); pPR272 loverexpresses ompF) (lane 2); pRAM1005 (control for pRAM1006) (lane 3); and pRAM1006 (overexpresses ompC) (lane 4). Lanes 5 and 6 show the $\beta$-galactosidase activities of PND2000 and PND257 (PND2000, om$p R:: \operatorname{Tn} 10 \mid$, respectively. Strains were grown in Luria broth with the appropriate antibiotic to select for plasmids when necessary (see Materials and methods for details.)

Silhavy 1995). LamBA23D contains a mutation that renders signal-sequence cleavage of this protein inefficient. High-level synthesis of this protein confers hypersensitivity to detergents, suggesting that LamBA23D perturbs the integrity of the outer membrane/Carlson and Silhavy 1993).

Independent attempts to identify extragenic suppressor mutations of the lethality conferred by either LamBLacZ-PhoA or LamBA23D yielded gain-of-function mutations in a previously identified locus, $c p x A$ (W.B. Snyder, C.L. Cosma, and T.J. Silhavy, unpubl.). $c p x A$ specifies an inner-membrane sensor homolog in the twocomponent family of regulatory proteins (Weber and Silverman 1988). $c p x R$, the gene specifying the putative cognate response regulator of CpxA, lies immediately upstream of the $c p x A$ locus and shares homology with other two-component response regulators (Dong et al. 1993).

Based on homology between $c p x A$ and this family of regulatory proteins, it seemed likely that the $c p x A$ suppressor mutations played a regulatory function in relieving the toxicity conferred by LamB-LacZ-PhoA and LamBA23D. Biochemical analysis has shown that the $c p x A$ suppressors enhance the rate of proteolysis of 
LamB-LacZ-PhoA (W.B. Snyder and T.J. Silhavy, unpubl.). This result prompted us to examine the effects of the $c p \times A$ suppressor mutations on transcription from our $\operatorname{deg} P-l a c Z$ fusion. Each $c p x A$ suppressor allele was transduced into the $\operatorname{deg} P-\operatorname{lac} Z$ fusion strain and the resulting $\beta$-galactosidase activity was determined. Figure 2 shows that the $c p \times A$ suppressor alleles increase transcription from the $\operatorname{deg} P-l a c Z$ fusion from 3- to 10-fold.

It is interesting to note that the $c p x A 24, c p x A 17$, and $c p \times A 41$ alleles were originally characterized as stronger suppressors of the lethality conferred by LamB-LacZPhoA than $c p x A 723, c p x A 741$, and $c p x A 744$ (W.B. Snyder and T.J. Silhavy, unpubl.). Figure 2 shows that $c p \times A 24, c p \times A 17$, and $c p \times A 41$ also increase transcription from $\operatorname{deg} P$ to a higher level than $c p x A 723, c p x A 741$, and $c p x A 744$. Thus, the $c p x A$ alleles that stimulate transcription of $\operatorname{deg} P$ most strongly are also the strongest cpXA suppressor alleles.

\section{Analysis of cpxA and cpxR null mutations}

Previous work has demonstrated that $\operatorname{deg} P$ transcription is modulated in response to the amount of outer-membrane proteins localized to the bacterial envelope (Mecsas et al. 1993). This effect is mediated by modulating the activity of $E \sigma^{\mathrm{E}}$, and presently the mechanism of this regulation is unknown. Because $\mathrm{CpxA}$ is an inner-membrane sensor homolog and because the $c p x A$ suppressors stimulate $\operatorname{deg} P$ transcription, it seemed possible that CpxA and CpxR were responsible for sensing the extra-

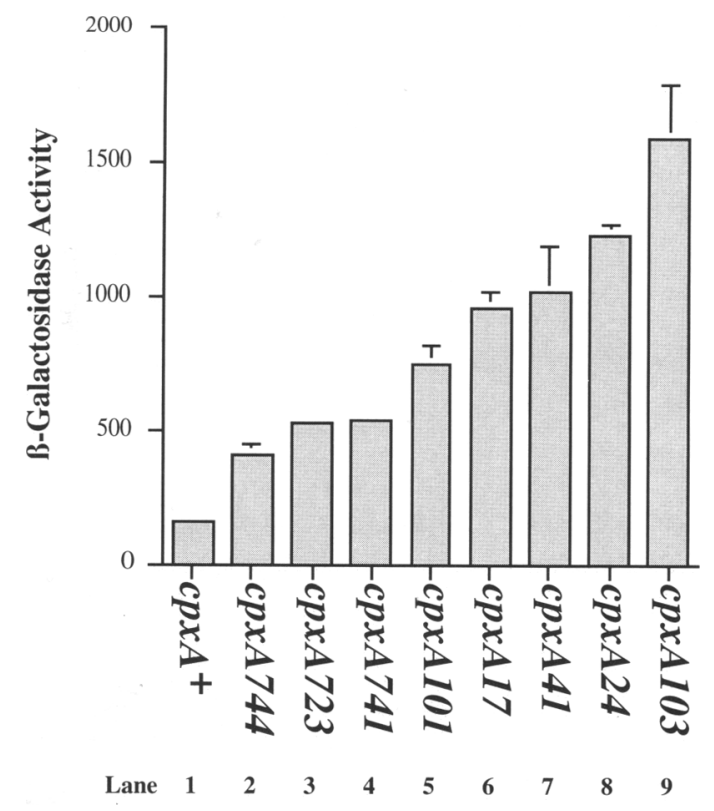

Figure 2. $\quad p \times A$ suppressor mutations activate transcription of degP-lacZ. $\beta$-Galactosidase activities of PND2000 (MC4100, $\lambda$ RS88[degP-lacZ]) (lane 1) and PND2000 containing the various mutant $c p x A$ alleles indicated (lanes $2-9$ ) were assayed. The mutant $\operatorname{cpx} A$ alleles stimulate transcription of $\operatorname{deg} P-\operatorname{lac} Z \sim 3$ to 10 -fold over that of wild type. Strains were grown in Luria broth as described in Materials and methods. cytoplasmic parameter that influences $E \sigma^{\mathrm{E}}$ activity. If the Cpx proteins were the sole sensory circuit for modulating $E \sigma^{\mathrm{E}}$ activity, $c p x$ null strains should no longer alter E $\sigma^{\mathrm{E}}$ activity in response to fluctuations in the number of outer-membrane proteins found in the bacterial envelope.

$c p \times A$ and $c p x R$ were each inactivated by insertion of antibiotic-resistance cassettes within their respective open reading frames (see Materials and methods). The insertion within $c p x R$ is polar and strains containing this insertion are $c p x R^{-}$and $c p x A^{-}$(see Materials and methods for details). When introduced into the $\operatorname{deg} P-l a c Z$ fusion strain, the $c p x A$ and $c p x R$ null alleles both conferred a decrease in transcription from this fusion (e.g., Fig. 3a, cf. lanes 1, 3, and 5). However, the cpx null mutations were not epistatic to transcriptional induction of the $\operatorname{deg} P-l a c Z$ fusion by any factors known to alter $E \sigma^{\mathrm{E}}$ activity. Specifically, overexpression of ompF or ompC still caused the same magnitude increase in transcription from the $\operatorname{deg} P-\operatorname{lac} Z$ fusion with or without functional Cpx proteins (Fig. 3a,b). Also, the ompR::Tn10 mutation decreases $\operatorname{deg} P$ transcription in the $c p x A^{-}$and $c p x A^{-} R^{-}$strains (Fig. 3c). Thus, $c p x A$ is not required for modulating $E \sigma^{E}$ activity under these circumstances.

\section{Acetyl-phosphate can stimulate $\operatorname{degP}$ transcription through $C p x R$}

Most two-component sensors are responsible for phosphorylating and dephosphorylating their cognate response regulators to elicit appropriate internal responses to a particular external input. The phosphorylated species of the response regulator is typically the species that actively elicits the internal responses (Stock et al. 1990; Parkinson 1993|. Many response regulators can also be phosphorylated by the low-molecular-weight compound, acetyl-phosphate (Ac $\sim$ P) (Lukat et al. 1992; McCleary et al. 1993). In wild-type cells, the effect of phosphorylation of response-regulators by $\mathrm{Ac} \sim \mathrm{P}$ is negligible. However, when a given sensor molecule is lost to mutation, the effect of phosphorylation of the cognate response regulator by Ac $\sim$ P can become significant. With the sensor molecule rendered nonfunctional, there is no phosphatase activity to counteract the phosphorylation of the response regulator by $\mathrm{Ac} \sim \mathrm{P}$ (McCleary et al. 1993). Because $A c \sim P$ can be synthesized from acetyl-CoA and $P_{i}$ (McCleary et al. 1993), the intracellular concentration of $A c \sim P$ rises with the use of the glycolytic pathway. Hence, carbon sources utilized in glycolysis increase the intracellular concentration of $\mathrm{Ac} \sim \mathrm{P}$, and this ultimately leads to an increase in the phosphorylation of certain "orphaned" response regulators.

Our analysis of the $c p \times A$ and $c p x R$ null mutations indicates that CpxR can be phosphorylated by $A c \sim P$ under certain conditions. When grown in Luria broth, the $c p \times A^{-}$strain displays a decrease in $\operatorname{deg} P$ transcription compared with an isogenic $c p x A^{+}$strain (Fig. $3 \mathrm{a}-\mathrm{c}$, cf. lanes 1 and $3 \mid$. However, when $c p \times A^{+}$and $c p \times A^{-}$strains are grown in the presence of carbon sources such as D-glucose, maltose, or lactose, the $c p x A^{-}$strain displays 
Figure 3. The Cpx proteins do not modulate $\operatorname{deg} P-l a c Z$ transcription in response to outer-membrane protein levels. (a) (Lanes $1,3,5) \quad \beta$-Galactosidase levels of strains transformed with pLG339 (control for pPR272); (lanes 2,4,6) $\beta$-galactosidase levels of strains transformed with pPR272 loverexpresses ompF). (b) (Lanes 1,3,5) $\beta$-galactosidase levels of strains transformed with pRAM1005 (control for pRAM1006); (lanes $2,4,6) \beta$-galactosidase levels of strains transformed with pRAM1006 (overexpresses ompC). (c) The Cpx proteins do not mediate the decrease in transcription from $\operatorname{deg} P$ lacZ conferred by the ompR::Tn10 mutation. (Lanes 1,3,5) ompR ${ }^{+}$; (lanes 2,4,6) $\operatorname{ompR}:: \operatorname{Tn} 10$. In $a-c$, lanes 1 and 2 display $\beta$-galactosidase levels of PND2000 [MC4100, $\lambda \mathrm{RS} 88\left[\operatorname{deg} P-l a c Z\right.$ ], $\quad c p \times A^{+}$, $c p \times R^{+}$); Lanes 3 and 4 display $\beta$-galactosidase levels of PND242 (PND2000, $c p x$ A::cam); lanes 5 and 6 display $\beta$-galactosi-

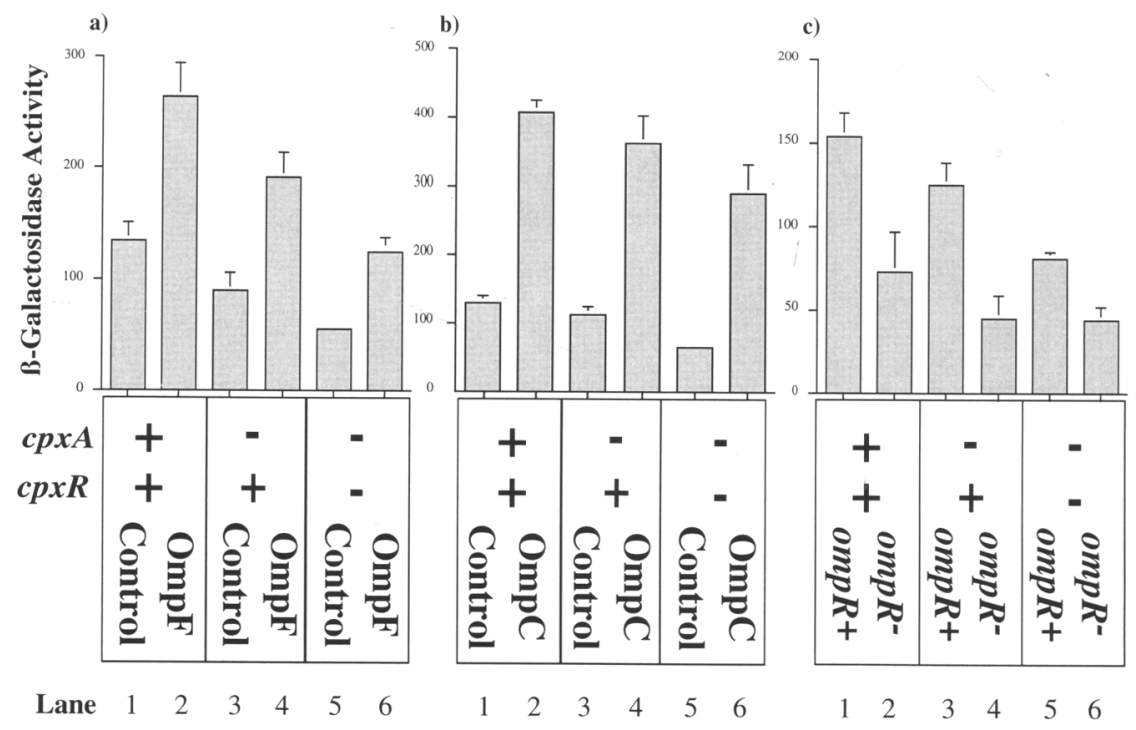
dase levels of PND325 (PND2000, cpxR:: $\Omega$ ). All strains were grown in Luria broth and the appropriate antibiotic for plasmid selection when necessary as described in Materials and methods.

a dramatic increase in $\operatorname{deg} P$ transcription (Fig. 4, cf. lanes 1 and 2 ; data not shown). In contrast, the $c p \times R^{-} A^{-}$dou-

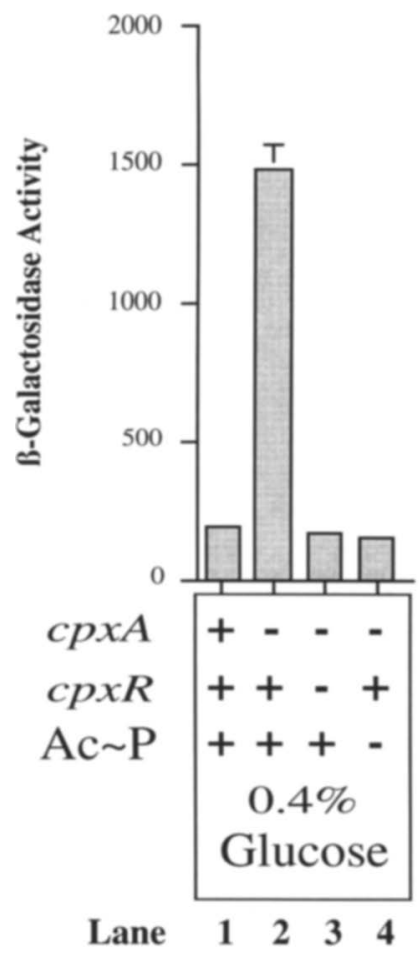

Figure 4. Ac $\sim P$ mediates transcriptional induction of $\operatorname{deg} P-$ lacZ by phosphorylating CpxR in the absence of CpxA. (Lane 1) PND495 (PND2000, zej::Tn10); (lane 2) PND422 (PND2000, cpxA::cam, zej::Tn10); (lane 3) PND496 (PND2000, cpxR:: $\Omega$, $z e j:: \operatorname{Tn} 10$ ); (lane 4) PND421 (PND2000, cpxA::cam, zej::Tn10 $\Delta[p t a, a c k A, h i s Q$, his $P] \mid$. Strains were grown in M63 minimal media with $0.4 \%$ glucose as a carbon source (see Materials and methods for details). ble mutant does not alter $\operatorname{deg} P$ transcription when grown in these same carbon sources (Fig. 4, cf. lanes 2 and 3), indicating that the transcriptional induction of $\operatorname{deg} P$ observed in the absence of $\mathrm{CpxA}$ proceeds through CpxR via another factor. This other factor is $\mathrm{Ac} \sim \mathrm{P}$. Deletion of pta and ack $A$, the two genes responsible for $\mathrm{Ac} \sim \mathrm{P}$ synthesis (McCleary et al. 1993), is epistatic to the effect of glucose on $\operatorname{deg} P$ transcription in a $c p x A^{-}$background (Fig. 4, cf. lanes 2 and 4 ). These results further imply that CpxR-phosphate (CpxR-P) can direct transcriptional induction of $\operatorname{deg} P$ and also provide indirect evidence that CpxA can dephosphorylate CpxR-P.

The Cpx pathway mediates transcriptional induction of degP in response to high-level synthesis of an envelope lipoprotein

The observed induction of $\operatorname{deg} P$ transcription by $A c \sim P$ in a $c p x A^{-}$background is clearly not a reflection of wildtype regulation. From the data presented thus far, several models can explain the Cpx-mediated transcriptional regulation of $\operatorname{deg} P$. For example, it is possible that the Cpx proteins are normally involved in transcriptional induction of $\operatorname{deg} P$ in response to an unknown extracytoplasmic parameter. If so, the observed induction of $\operatorname{deg} P$ synthesis by $\mathrm{Ac} \sim \mathrm{P}$ or $c p x A$ mutations has simply highlighted a normal function of the Cpx pathway by perturbing this pathway. It is also possible that the Cpx proteins normally regulate the synthesis of an outermembrane protein which, when overproduced by activation of the Cpx pathway, increases E ${ }^{\mathrm{E}}$ activity, ultimately stimulating transcription of $\operatorname{deg} P$. Alternatively, the induction of $\operatorname{deg} P$ transcription by $\mathrm{Ac} \sim \mathrm{P}$ in the $c p x A$ null strain or by the $c p x A$ mutations could reflect situations whereby a hyperactivated Cpx pathway would al- 
ter the transcription of genes outside of its normal regulon. Evidence presented below favors the first model.

In an independent attempt to identify high-copy suppressors of the lethality conferred by LamB-LacZ-PhoA, a new envelope lipoprotein, NlpE, was identified (W.B. Snyder, L.J.B. Davis, and T.J. Silhavy, unpubl.). Highlevel synthesis of NlpE increases transcription of $\operatorname{deg} P$ 10-fold (Fig. 5, lanes 1,2) and suppresses the lethality conferred by LamB-LacZ-PhoA. In this case, transcriptional induction of $\operatorname{deg} P$ is dependent on CpxA. There is no induction of $\operatorname{deg} P$ transcription by overproduction of $\mathrm{NlpE}$ in either the $c p \times A^{-}$or $c p \times R^{-} A^{-}$backgrounds (Fig. 5), and the synthesis of NlpE itself is unaffected by the cpx null mutations (data not shown). The Cpx-dependent transcriptional induction of $\operatorname{deg} P$ highlights two points: (1) The wild-type Cpx proteins can activate $\operatorname{deg} P$ transcription in response to an extracytoplasmic stimulus, and (2) the observed transcriptional induction of $\operatorname{deg} P$ by $A c \sim P$ and the $c p x A$ suppressor mutations likely reflects a normal function of the $\mathrm{Cpx}$ pathway even

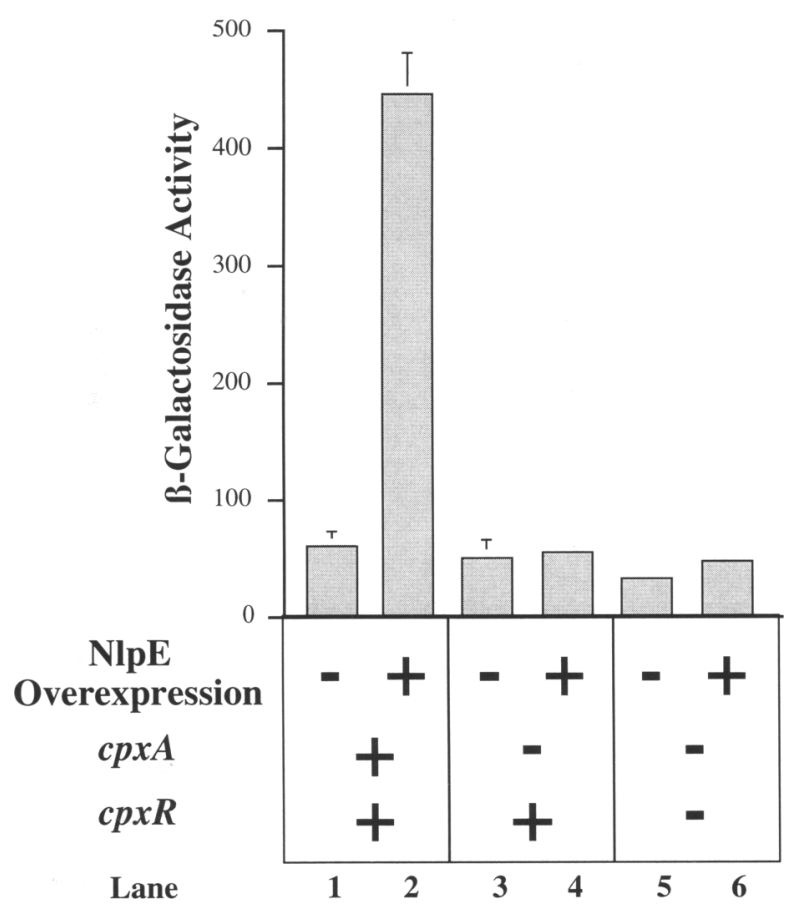

Figure 5. Overexpression of nlpE induces transcription of $\operatorname{deg} P-\operatorname{lac} Z$ through the Cpx signal transduction pathway. (Lanes $1,3,5) \quad \beta$-Galactosidase activity of strains transformed with pBAD18 (control for pND18); (lanes 2,4,6) $\beta$-galactosidase activity of strains transformed with pND18 (overexpresses nlpE). (Lanes 1,2) PND497 (PND2000, zej::Tn10 $\Delta[p t a, ~ a c k A$, hisQ, hisP], ara ${ }^{+}$; (lanes 3,4) PND498 (PND497, cpxA::cam); (lanes 5,6) PND499 (PND497, cpxR:: $\Omega$ ). All strains were grown in Luria broth containing $0.4 \% \mathrm{~L}$-arabinose and $50 \mu \mathrm{g} / \mathrm{ml}$ of ampicillin (see Materials and methods for details). The experiments in Figure 5 were performed with strains deleted for pta and $a c k A$. Because NlpE synthesis is driven from the araB promoter (Guzman et al. 1992) in this experiment, full transcriptional induction requires growth in arabinose. Hence, Ac $\sim \mathrm{P}$ synthesis must be eliminated to prevent hyperphosphorylation of CpxR in the $c p x R^{+} A^{-}$background. though the observed induction occurs by perturbing this pathway.

The Cpx pathway is not a general monitor of lipoprotein synthesis

Because overproduction of NlpE activates $\operatorname{deg} P$ transcription via the Cpx pathway, it seemed possible that the Cpx proteins were responsible for modulating $\operatorname{deg} P$ transcription in response to the high-level synthesis of lipoproteins in general. In this case, the Cpx pathway would alter $\operatorname{deg} P$ transcription in response to the level of lipoproteins, just as $\operatorname{deg} P$ transcription is modulated in response to the levels of outer-membrane proteins (Mecsas et al. 1993). However, high-level synthesis of a variety of lipoproteins, including OsmB (Jung et al. 1989), Lpp (Nakamura et al. 1982), Pal (Chen and Henning 1987), lipoprotein-28 (Yu et al. 1986), NlpD (Ichikawa et al. 1994), and TraT (Ogata et al. 1982), does not induce transcription of $\operatorname{deg} P-l a c Z$ (data not shown). Thus, the Cpx pathway does not appear to monitor lipoprotein synthesis in general, implying that the enhanced transcription observed by overexpression of $n l p E$ is related to the actual function of NlpE.

The Cpx pathway activates transcription from $\operatorname{degP}$ but not transcription from a minimal $\mathrm{rpoH}_{\mathrm{P} 3}$ promoter

Presently, there are only two promoters in E. coli that are known to be utilized by $\mathrm{E \sigma}^{\mathrm{E}}$ : the $\operatorname{deg} P$ promoter and the $P 3$ promoter of rpoH (Lipinska et al. 1988; Erickson and Gross 1989; Wang and Kaguni 1989|. Using a rpoH ${ }_{P 3}-$ lacZ operon fusion, Mecsas et al. (1993) have shown that the minimal $P 3$ promoter is regulated by $E \sigma^{E}$ in a fashion analogous to that seen with the $\operatorname{deg} P$ promoter.

We wished to determine whether activation of the Cpx pathway directly altered $\sigma^{\mathrm{E}}$ levels. If this were true, activation of the Cpx pathway would affect transcription of the $\mathrm{rpoH}_{P 3}-\mathrm{lacZ}$ fusion in a fashion similar to that observed with $\operatorname{deg} P$. However, activation of the Cpx pathway had no effect on transcription from the $\mathrm{rpoH}_{P 3}-\mathrm{lacZ}$ operon fusion. Figure $6 \mathrm{a}$ shows that in a $c p \times A^{-}$background, carbon sources such as glucose do not affect transcription from the $r p o H_{P 3}$ promoter (cf. lanes 1 and 2). This is in contrast to the 10 -fold stimulation of $\operatorname{deg} P$ transcription observed under the same conditions /see Fig. 4). Also, whereas overexpression of ompX or ompC stimulates transcription from both $\mathrm{rpoH}_{P 3}$ and $\operatorname{deg} P$ (Fig. 6b, lanes 2,4; Mecsas et al. 1993), overexpression of nlpE has no effect on $\mathrm{rpoH}_{P 3}$ transcription (Fig. 6b, lane 6). These results reveal a new layer in the regulation of $\operatorname{deg} P$ transcription. The Cpx pathway does not directly alter $\sigma^{\mathrm{E}}$ levels. Rather, this pathway affects $\operatorname{deg} P$ transcription by working in parallel with $\mathbf{E} \sigma^{\mathbf{E}}$.

\section{Activation of degP transcription by the Cpx pathway is dependent on $E \sigma^{E}$ activity}

The fact that activation of the Cpx pathway stimulated transcription of $\operatorname{deg} P$ and not of $r p o H_{P 3}-l a c Z$ suggested 
Figure 6. Activation of the Cpx signal transduction pathway does not stimulate transcription from $\mathrm{rpoH}_{\mathrm{P}_{3}}-\mathrm{lacZ}$. (a) $\mathrm{Ac} \sim \mathrm{P}$ does not stimulate transcription of $r \mathrm{poH}_{P 3}-$ $l a c Z$ in the absence of CpxA. (Lane 1)

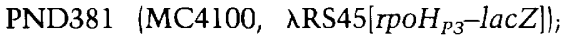
(lane 2 PND394 (PND381, cpxA::cam); (lane 3) PND393 (PND381, cpxR:: $\Omega$ ). All strains in $a$ were grown in M63 minimal media with $0.4 \%$ glucose. $\{b\}$ Overexpression of nlpE does not stimulate transcription of $\mathrm{rpoH}_{P 3}-\mathrm{lacZ}$. All lanes show the $\beta$-galactosidase activity of PND500 (PND381, $\mathrm{ara}^{+}$) transformed with pBR322 (control for pJE100) (lane 1); pJE100 (overexpresses ompX) (lane 2); pRAM1005 (control for pRAM 1006) (lane 3); pRAM1006 (overexpresses ompC) (lane 4); pBAD18 (control for pND18) (lane 5); pND18 (overexpresses nlpE) (lane 6). Strains in lanes 1-4 were grown in Luria broth with the appropriate antibiotic to select for plasmids; strains in lanes 5 and 6 were grown in Luria broth with $0.4 \% \mathrm{~L}$-arabinose to stimulate transcription from the $a r a B$ promoter.

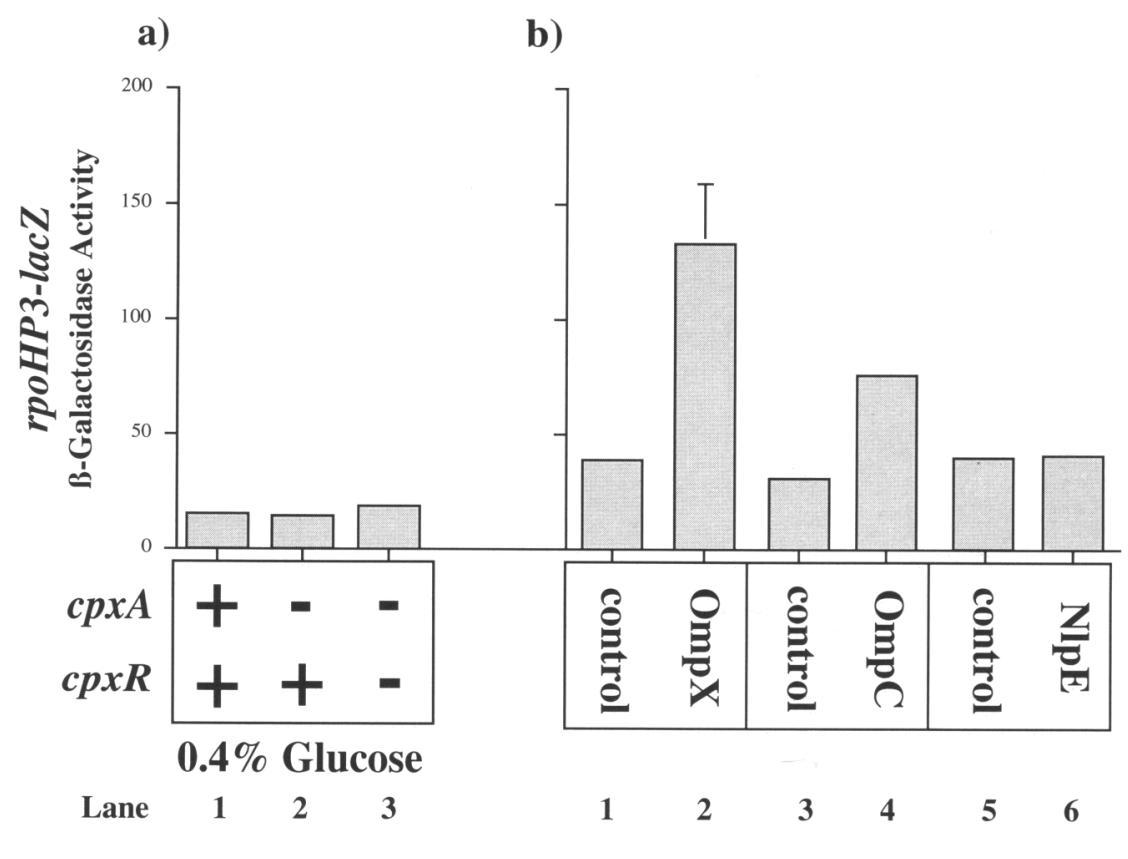

that the Cpx pathway functions specifically at the $\operatorname{deg} P$ promoter, perhaps working in concert with $\mathrm{E}^{\mathrm{E}}$ to activate $\operatorname{deg} P$ transcription. If this were true, activation of $\operatorname{deg} P$ transcription by the Cpx pathway would be dependent on a functional copy of the rpoE gene, which encodes $\sigma^{\mathrm{E}}$ (Raina et al. 1995; Rouviere et al. 1995). Figure 7 indicates that activation of $\operatorname{deg} P$ transcription by the Cpx pathway is partially dependent on the activity of $\mathrm{E}^{\mathrm{E}}$. Inactivation of $r p o E$ decreases the transcriptional induction of $\operatorname{deg} P$ by overexpression of $n l p E$ (Fig. 7, cf. lanes 2 and 4). The results illustrated in Figure 7 suggest that the Cpx pathway can function in concert with $\mathrm{E \sigma}^{\mathrm{E}}$ to induce $\operatorname{deg} P$ transcription. However, the rpoE null mutation is not completely epistatic to the transcriptional induction of $\operatorname{deg} P$ by activation of the Cpx pathway. This indicates that the Cpx pathway can function in concert with at least one other RNA polymerase to drive $\operatorname{deg} P$ transcription.

It should be noted that the experiments performed to generate the data illustrated in Figure 7 utilized the $\operatorname{deg} P-\operatorname{lacZ}$ fusion in the MC1061 (Silhavy et al. 1984) strain background. This was necessitated because of the instability of the rpoE::cam mutation in the MC4100 background (P.N. Danese, unpubl.). Importantly, this change in strain background is not problematic, as it does not affect the observed transcriptional regulation of $\operatorname{deg} P$ in response to activation of the Cpx pathway (cf. lanes 1 and 2 in Fig. 7 with lanes 1 and 2 in Fig. 5).

Because the transcriptional induction of $\operatorname{deg} P$ observed by activation of the Cpx pathway was not entirely dependent on $\mathrm{E \sigma}^{\mathrm{E}}$, we were interested in determining the transcriptional initiation sites for the Cpx-mediated induction. S1 nuclease mapping of the transcription start sites of $\operatorname{deg} P$ was performed with RNA prepared from $r p o E^{+}$strains that contained either an $n l p E$-overexpressing plasmid (pND18) or a control plasmid (pBAD18). Figure 8 shows the transcripts induced by overexpression of nlpE. These transcripts begin between nucleotides 147 and 165 of the published $\operatorname{deg} P$ sequence (Lipinska et al. 1988). Figure 8a shows that transcription initiated at position 159, which is attributed to E $\sigma^{\mathrm{E}}$ (Lipinska et al. 1988; Erickson and Gross 1989), can be induced by the Cpx pathway. This is consistent with the results presented in Figure 7, indicating that the Cpx pathway can function in concert with $\mathrm{E \sigma}^{\mathrm{E}}$ to activate $\operatorname{deg} P$ transcription. Figure 8a also shows the induction of other transcripts that initiate near position 159. Presently, we do not know which (if any) of these other transcripts is also a product of $\mathrm{Eo}^{\mathrm{E}}$-directed transcription. However, we note that activation of the Cpx pathway generates novel protected fragments initiating at positions 147 and 148 which are not present in the uninduced strain (Fig. 8a, cf. lanes 1 and 2). These fragments may represent the source of the residual transcriptional induction of $\operatorname{deg} P$ by the Cpx pathway in the absence of $\sigma^{\mathrm{E}}$.

\section{Discussion}

The molecular nature of the pleiotropic cpxA mutations

cpxA was first identified by mutations that prevented efficient transfer of $F$ plasmids from donor to recipient strains (conjugative plasmid expression) (McEwen and Silverman 1980a). Subsequent analyses have shown that these alleles, as well as the $c p x A$ suppressor mutations identified in our laboratory (see Figure 2), are highly pleiotropic. For example, these $c p x A$ mutations confer 


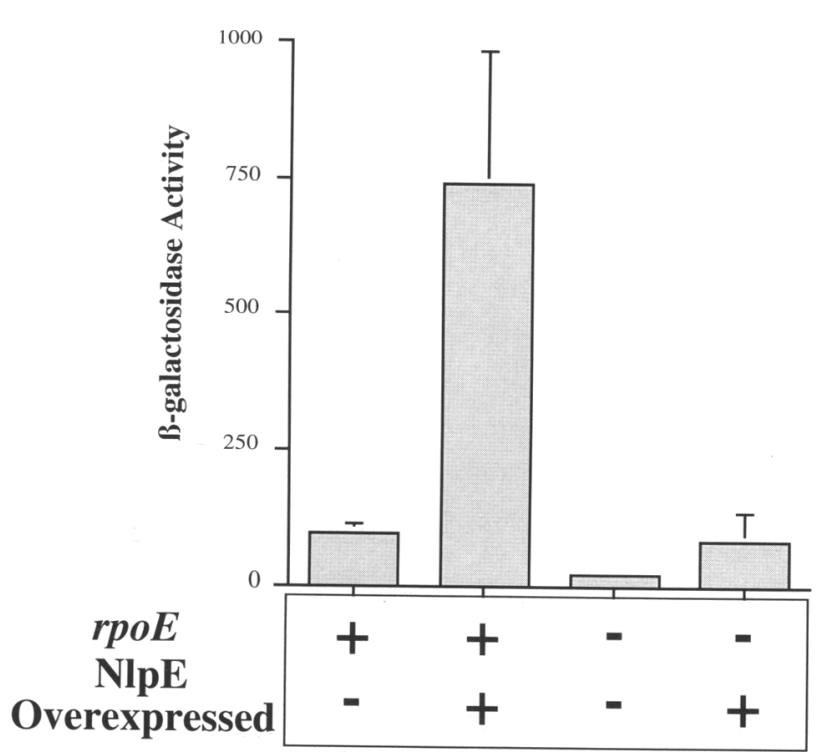

Figure 7. Cpx-mediated stimulation of $\operatorname{deg} P$ transcription is partially dependent on the activity of $\mathrm{E}^{\mathrm{E}}$. (Lanes 1,3$) \beta$-Galactosidase activity of strains transformed with pBAD 18 /control for pND18); (lanes 2,4) $\beta$-galactosidase activity of strains transformed with pND18 (overexpresses nlpE). (Lanes 1,2) PND819 (MC1061 $\lambda$ RS88|degP-lacZ]); (lanes 3,4) PND818 (MC1061, $\lambda$ RS88[ $\operatorname{deg} P-l a c Z$ ] rpoE::cam). All strains were grown at $30^{\circ} \mathrm{C}$ in Luria broth containing $0.4 \% \mathrm{~L}$-arabinose and $50 \mu \mathrm{g} / \mathrm{ml}$ of ampicillin (see Materials and methods for details). Although the standard deviation for the $\beta$-galactosidase activity shown in lane 4 is relatively large, Student's $t$-test for comparison of two means indicates that the difference between the values shown in lanes 3 and 4 is statistically significant at a confidence level $>0.99$ (Harris 1987).

many (but not necessarily all) of the following phenotypes: decreased stability of inner- and outer-membrane proteins, including Lpp and $\mathrm{OmpF}$; low-level resistance to aminoglycosides; impairment of ion-driven transport systems such as those for lactose and proline; inability to grow on nonfermentable carbon sources such as succinate; the ability to utilize L-serine as a carbon source; and isoleucine/valine auxotrophy $(\mathrm{McE}$ wen and Silverman 1980b, 1982; Rainwater and Silverman 1990; Dong et al. 1993).

Our analysis indicates that the pleiotropic cpxA mutations are not null mutations. Whereas the pleiotropic $c p \times A$ suppressors increase $\operatorname{deg} P$ transcription, a defined $c p \times A$ null mutation actually decreases $\operatorname{deg} P$ transcription in the absence of cross-phosphorylation by $A c \sim P$. Moreover, the $c_{x} A$ null also unveils the basis for the observed pleiotropy of the $c p x A$ missense mutations. These mutant CpxA proteins phosphorylate $\mathrm{CpxR}$ in an unregulated manner and ultimately cause CpxR-P to accumulate to high levels. Under these conditions, transcription from genes normally regulated by $\mathrm{CpxR}$ is altered and the regulation of genes not normally found in the $c p x$ regulon is affected as well. Thus, the pleiotropic mutations probably disrupt the phosphatase activity or enhance the kinase activity of CpxA. This is not unprec- edented behavior for a two-component sensor. The $E$ coli osmosensor EnvZ can be altered by mutation to a phosphatase ${ }^{-}$kinase $^{+}$species, and this mutant EnvZ hyperphosphorylates its cognate response regulator, OmpR, ultimately altering transcription from its normal downstream targets, $o m p F$ and $o m p C$, as well as other loci (Slauch et al. 1988).

This model also clarifies another observation in the $c p x$ literature. Many of the previous phenotypic characterizations of the pleiotropic $c p x A$ mutations noted that a large chromosomal deletion encompassing $c p \times A$ and spanning from $r h a$ to $p f k A$ reverted the pleiotropic phenotypes (Dong et al. 1993). However, the precise meaning of the results obtained with this deletion is confounded by its sheer size. The deletion removes several genes and at least $10 \mathrm{~kb}$ of DNA (Miller 1992). From our analysis, it is clear that deletion of both $c p x A$ and $c p x R$ prevents activation of the Cpx pathway altogether.

\section{The function of the Cpx proteins}

Whereas there are a variety of phenotypes conferred by

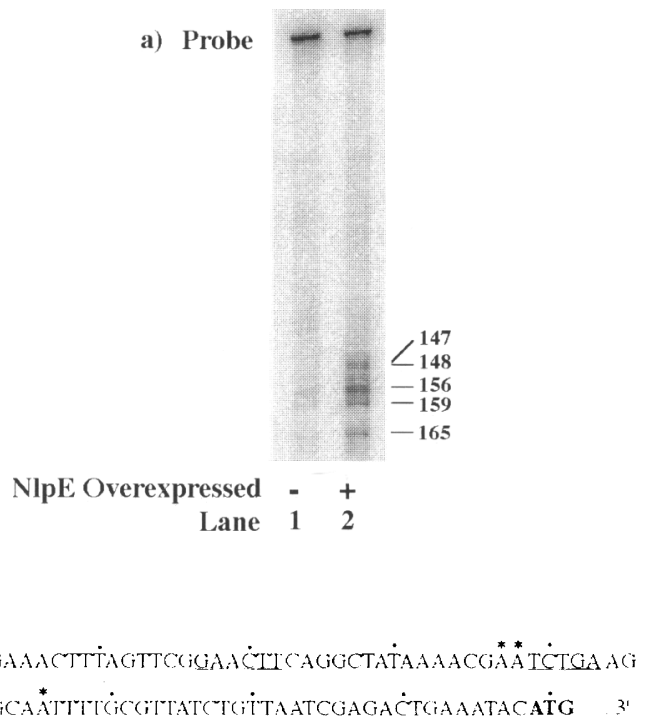

Figure 8. Activation of the Cpx pathway stimulates $\operatorname{deg} P$ transcription at the $\sigma^{\mathrm{E}}$ promoter and nearby sites. $(a)$ Lanes 1 and 2 show the $\operatorname{deg} P$ transcription start sites for strain PND2000 ara ${ }^{+}$ transformed with either a control plasmid, pBADl8 (lane 1), or the $n l p E$-overexpressing plasmid, pNDl8 (lane 2). The undigested probe ( 340 nucleotides in length) is shown. The DNA fragments corresponding to transcripts that initiate at positions $147,148,156,159$, and 165 of the $\operatorname{deg} P$ sequence (Lipinska et al. 1988 ) are indicated at right. RNA was prepared from strains grown at $30^{\circ} \mathrm{C}$ in Luria broth containing $0.4 \% \mathrm{~L}$-arabinose and $50 \mu \mathrm{g} / \mathrm{ml}$ of ampicillin. (see Materials and methods for details). (b) The transcription start sites are designated with asterisks (*). The sequence illustrated in $b$ spans from nucleotide 106 to 201 of the published sequence (Lipinska et al. 1988). The -10 and -35 sites of the $\sigma^{\mathrm{E}}$ promoter are underlined, and the first codon of the $\operatorname{deg} P$ open reading frame is shown in boldface type. Periods are spaced every 10 nucleotides for reference. 
the pleiotropic cpxA mutations (see above), it is unclear whether these phenotypes reflect a normal function of the Cpx proteins or whether they are attributable to aberrant properties of the hyperactivated Cpx pathway. For example, Silverman has examined the effects of $c p x A$ mutations on $F$ plasmid transmission. These studies have shown that the pleiotropic $c p x A$ mutations decrease the steady-state levels of the cytoplasmic TraJ protein (Silverman et al. 1993), providing an explanation for the inefficient transfer. However, deletion of the $c p x$ genes reverts the $\mathrm{F}$ plasmid transfer phenotypes to a wild-type state (Silverman et al. 1993), suggesting that the effects observed on $F$ plasmid transfer may reflect aberrant properties of the hyperactivated Cpx pathway.

In contrast, the data presented here suggest that the Cpx proteins are normally involved in regulating $\operatorname{deg} P$ transcription. First, the $c p x R^{-} A^{-}$double mutant decreases $\operatorname{deg} P$ transcription twofold, indicating that the Cpx proteins normally contribute to $\operatorname{deg} P$ transcription in a wild-type cell. Second, activation of the Cpx pathway (either by $\mathrm{Ac} \sim \mathrm{P}$ or by mutation of $c p x A$ ) increases $\operatorname{deg} P$ transcription 3- to 10 -fold. Third, an extracytoplasmic stimulus ( $n l p E$ overexpression) activates $\operatorname{deg} P$ transcription through the wild-type Cpx proteins, arguing that transcriptional induction of $\operatorname{deg} P$ is a normal function of the Cpx pathway.

Although the precise molecular basis for many of the other phenotypes conferred by the pleiotropic cpxA mutations remains to be determined, at least a subset of these phenotypes may be attributable to the activation of $\operatorname{deg} P$ transcription. For example, Silverman and colleagues noted that both inner- and outer-membrane proteins, including Lpp and $\mathrm{OmpF}$, were destabilized in a cpXA2 background (McEwen and Silverman 1982; McEwen et al. 1983). It seems likely that this phenotype is attributable to activation of $\operatorname{deg} P$ transcription. Other phenotypes such as low-level resistance to aminoglycosides and impairment of ion-driven transport systems also originate from alterations in the physiology of the bacterial envelope (Rainwater and Silverman 1990). It is possible that these phenotypes are also attributable to the destabilization of certain envelope proteins by increased levels of DegP.

\section{The Cpx regulon}

The Cpx pathway stimulates transcription at sites upstream of the $\operatorname{deg} P$ open reading frame, including the site utilized by E $\sigma^{\mathrm{E}}$ (Figs. 7 and 8 ). The simplest explanation for this result is that CpxR binds to a site upstream of the $\operatorname{deg} P$ open reading frame and works in concert with $\mathrm{E}^{\mathrm{E}}$ and perhaps other RNA polymerases to drive $\operatorname{deg} P$ transcription (Fig. 9). CpxR shares homology with other twocomponent DNA-binding proteins, including OmpR and ArcA (Dong et al. 1993). There are $>100$ nucleotides upstream of the -35 site of $\operatorname{deg} P$ in our $\operatorname{deg} P-l a c Z$ operon fusion which could support binding of $\mathrm{CpxR}$. However, direct biochemical analysis is required to test this model.

Whereas activation of the Cpx pathway does not increase transcription from $\mathrm{rpoH}_{\mathrm{P}_{3}}-\mathrm{lacZ}$, it is still possible that the Cpx proteins might influence transcription from $r p o H_{P 3}$ at its wild-type chromosomal locus. In the ${ } p o H_{P 3}-l a c Z$ fusion, only the minimal promoter containing the -10 and -35 sites of $\mathrm{rpoH}_{p 3}$ is used to drive transcription (Mecsas et al. 1993). There are no upstream sequences present in this fusion that could potentially support binding of transcription factors. Thus, we do not know whether the Cpx regulon stimulates transcription at other $\sigma^{\mathrm{E}}$ promoters or whether the $\mathrm{Cpx}$ and $\sigma^{\mathrm{E}}$ regulons simply intersect at $\operatorname{deg} P$. There is reason to believe that $\operatorname{deg} P$ is only one of a group of genes regulated by the

Figure 9. A model for the action of the Cpx signal transduction pathway on $\operatorname{deg} P$ transcription. The CpxA inner-membrane sensor responds to the level of the $\mathrm{NlpE}$ lipoprotein present in the bacterial envelope. CpxA communicates this information to its cognate response regulator, $\mathrm{CpxR}$, which in turn activates $\operatorname{deg} P$ transcription by working in concert with $\mathrm{E}^{\mathrm{E}}$ and perhaps other RNA polymerases. The activity of $E \sigma^{\mathrm{E}}$ is modulated by an unknown signal transduction system in response to the expression level of outer-membrane proteins.

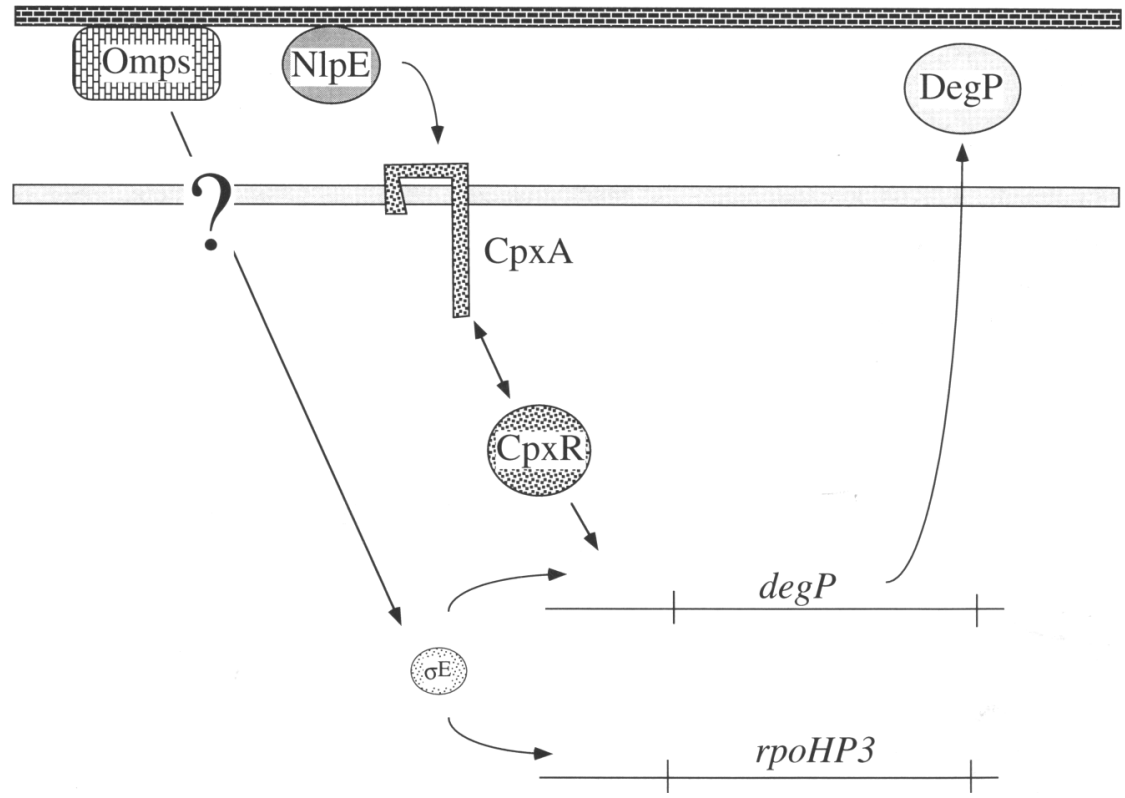


Cpx pathway. Although the toxicity conferred by induction of either LamB-LacZ-PhoA or LamBA23D is suppressed by activation of the Cpx pathway, removal of a functional $\operatorname{deg} P$ gene is only partially epistatic to the suppression, indicating that other gene products participate in the observed suppression (W.B. Snyder, C.L. Cosma, and T.J. Silhavy, unpubl.).

\section{What does CpxA sense?}

The Cpx proteins regulate $\operatorname{deg} P$ transcription in response to the high-level synthesis of the envelope lipoprotein $\mathrm{NlpE}$. However, increased levels of lipoproteins in general do not induce transcription of $\operatorname{deg} P-l a c Z$, implying that the enhanced transcription of $\operatorname{deg} P$ caused by overexpression of $n l p E$ is probably related to the actual function of NlpE. Presently, this function is unknown, but we suggest that NlpE may be regulated in response to some physiological parameter associated with the outer membrane. Alteration of the levels and/or activity of $\mathrm{NlpE}$ would be communicated to the Cpx pathway to appropriately alter envelope physiology. We note that NlpE contains a serine protease inhibitor motif (W.B. Snyder, unpubl.). If NlpE is a protease inhibitor, CpxA may sense the need for increased expression of $\operatorname{deg} P$ and other gene products when the function of another envelope protease is inhibited.

\section{Materials and methods \\ Media, reagents, and enzymes}

Media were prepared as described by Silhavy et al. (1984). Liquid cultures were grown either in Luria broth or M63 minimal medium supplemented with thiamine $(50 \mu \mathrm{g} / \mathrm{ml})$ and $0.4 \%$ of the indicated carbon source. The final concentration of antibiotics used in the growth medium was as follows: $50 \mu \mathrm{g} / \mathrm{ml}$ of ampicillin; $50 \mu \mathrm{g} / \mathrm{ml}$ of kanamycin; $20 \mu \mathrm{g} / \mathrm{ml}$ of tetracycline; 50 $\mu \mathrm{g} / \mathrm{ml}$ of spectinomycin; $20 \mu \mathrm{g} / \mathrm{ml}$ of chloramphenicol. Standard microbiological techniques were used for strain construction and bacterial growth (Silhavy et al. 1984).

\section{Strains}

PND2000 (MC4100 $\lambda R S 88[\operatorname{deg} P-1 a c Z])$ is the parent of all strains containing the $\operatorname{deg} P-\operatorname{lac} Z$ operon fusion except for strains used to generate data illustrated in Figure 7 . Strains described in Figure 7 contain the $\operatorname{deg} P-l a c Z$ fusion in strain MC1061. The use of the MC1061 background for experiments described in Figure 7 was necessitated because of the instability of the rpoE::cam mutation in the MC4100 background. Lysogenization of $\lambda \mathrm{RS} 88$ [degP-lacZ] was performed as described by Simons et al. (1987). PND381 (MC4100 $\lambda$ RS45[rpo $H_{p 3}-l a c Z$ ]) is the parent of all strains containing the $\mathrm{rpoH}_{P 3}-\mathrm{lacZ}$ operon fusion. PND381 was created by P1 transduction using CAGl6037 (Mecsas et al. 1993) as a donor strain. All fusions were shown to be located in single copy at the $\lambda a t$ locus by Pl transduction. cpxA suppressor mutations were moved by $\mathrm{P} 1$ transduction, selecting for growth on minimal media with a met $F^{-}$recipient strain. The presence of the $c p x A$ suppressor mutations was verified by rescuing each allele by $\mathrm{P} 1$ transduction and demonstrat- ing the suppressor function of each allele in strains carrying

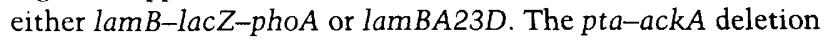
was moved by a linked transposon $(z e j:: \operatorname{Tn} 10)$, and the presence of the deletion was scored by assaying growth on minimal acetate media (Wanner and Wilmes-Reisenberg 1992). The cpx$A:: c a m, c p x R:: \Omega$, ompR::Tn10, and rpoE::cam mutations were moved by $\mathrm{P} 1$ transduction selecting for resistance to the appropriate antibiotic [(cam) chloramphenicol; $(\Omega)$ spectinomycin; (Tn10) tetracycline]. The rpoE::cam insertion (Rouviere et al. 1995 ) was assayed further for the conferral of temperature-sensitive growth at $42^{\circ} \mathrm{C}$.

\section{Plasmids and phage}

$\lambda$ RS88 has been described elsewhere (Simons et al. 1987). The following kanamycin-resistant plasmids were used in this study: pPR272 (overexpressing ompF; Misra and Reeves 1987); pLG338 (parent of pPR272 and pRC2; Stoker et al. 1982); pGPl-2 (T7 RNA polymerase for overexpression of nlpD; Ichikawa et al. 1994); pRC2 [overexpresses the gene for peptidoglycan-associated lipoprotein (pal); Chen and Henning 1987). The following ampicillin-resistant plasmids were used in this study: pRAM1005 (parent plasmid for pRAM1006; Misra and Benson 1988); pRAM 1006 (overexpresses ompC; Misra and Benson 1988); pJE100 (overexpresses ompX; Mecsas et al. 1993); pBR322 (parent of pJE100); pJKI10 (overexpresses nlpD; Ichikawa et al. 1994); pCG242 (overexpresses osmB; Jung et al. 1989); pOW3 (overexpresses traT; Ogata et al. 1982); pFY108 (overexpresses the gene for lipoprotein-28; Yu et al. 1986); pKEN125 (overexpresses lpp; Nakamura et al. 1982); pND18 (overexpresses nlpE; this study); pBAD18 (parent for pND18; Guzman et al. 1992). The expression levels of the various lipoproteins are at least 10 -fold greater than with control plasmids, spanning a range that exceeds $(\mathrm{Lpp})$, is comparable to (NlpD, Lpp-28), or is less than (TraT, Pal, OsmB) the level of NlpE when it is overproduced (Nakamura et al. 1982; Ogata et al. 1982; Yu et al. 1986; Henning 1987; Jung et al. 1989; Ichikawa et al. 1994).

pND1 8 was constructed as follows: $n l p E$ was amplified from the chromosome of MC4100 by the polymerase chain reaction (PCR) using the following primers: Nlpe5 $\left(5^{\prime}\right.$-TCAAGCGTGAAGTCGACGCGCGGCAAAGTG-3') and Nlpe3 (5'-GATGCGGCGTAAAAGCTTTATCCGGCC-3\%. Sall and HindIII restriction endonuclease sites were incorporated into $\mathrm{Nlpe} 5$ and Nlpe3, respectively, to facilitate subcloning. The amplified DNA was then subcloned into the SalI and HindIII sites of pBAD18, creating pND18. pND18 places nlpE under the transcriptional control of the $a r a B$ promoter (Guzman et al. 1992).

\section{Construction of the degP-lacZ fusion}

The $\operatorname{deg} P-l a c Z$ fusion was created by amplifying the chromosomal $\operatorname{deg} P$ locus of MC4100 by PCR using the following primers: Htra5 $\left(5^{\prime}\right.$-GCGTGGGATGAATTCCGACGTCTGATGG-3') and Htramid3 (5'-CCATGTTACCCGGGATAGCAAAACCG3-3'). EcoRI and SmaI restriction endonuclease sites were incorporated into Htra5 and Htramid3, respectively, to facilitate subcloning of the amplified DNA. This amplified DNA was subcloned into the EcoRI and SmaI sites of pRS415 (Simons et al. 1987), creating pSINATRA131. The nucleotide sequence of the $\operatorname{deg} P$ insert of PSINATRA 131 was confirmed by dideoxy nucleotide sequencing. The cloned $\operatorname{deg} P$ insert includes nucleotides from position -122 with respect to the $\operatorname{deg} P$ transcription start site to position +845 with respect to this same site. The $\operatorname{deg} P-\operatorname{lac} Z$ fusion of pSINATRA131 was then recombined onto phage $\lambda$ RS88 (Simons et al. 1987), and recombinants 
were used to lysogenize MC4100 as described (Simons et al. 1987).

\section{Construction of the cpxA and cpxR null mutations}

The chromosomal $\operatorname{cpx} A$ locus was amplified by PCR using the following primers: Cpxkpn $\left(5^{\prime}\right.$-GTTAACCGGTACCGAGTTTACCCTGC-3'); Cpxa3 (5'-CCGGAGTGTAGGCCTGATAAG-3'). KpnI and StuI restriction endonuclease sites were incorporated into Cpxkpn and Cpxa3, respectively, to facilitate subcloning. The amplified $c p \times A$ DNA was then subcloned into the KpnI and SmaI sites of pAMPTs (G. Phillips, unpubl. plasmid), creating $\mathrm{pND}$. The pAMPTs vector is temperature sensitive for replication. Strains grown in media selecting for this plasmid at the restrictive temperature $\left(42^{\circ} \mathrm{C}\right)$ must integrate the plasmid into the host chromosome to maintain viability. This temperature-sensitive replication provides a means for replacing chromosomal DNA with homologous plasmid-encoded DNA (Hamilton et al. 1989).

pND8 contains a unique EcoRI restriction site within the open reading frame of $c p x A$. This EcoRI site lies upstream of the codon for the conserved histidine residue of two-component sensors (Weber and Silverman 1988; Stock et al. 1990). The chloramphenicol antibiotic resistance cassette described by Fellay et al. (1987) was inserted within the $c p x A$ open reading frame at the unique EcoRI site, creating pND9. This insertion/ disruption of $c p \times A$ was then recombined onto the chromosome of MC4100 as described in Hamilton et al. (1989).

The $c p x R$ locus was inactivated in a similar fashion to $c p x A$. Using primers Cpxr5 (5'-GATATCCACCAGCGGATCCACCAGCGCG-3') and Cpxr3 (5'-CGTTGGGCGGATCCTTCGCCAGCTCCG-3'), $c p x R$ was amplified from the MC4100 chromosome by PCR. To facilitate the subcloning of $c p x R, B a m H I$ restriction endonuclease sites were incorporated into primers Cpxr5 and Cpxr3. The amplified $c p x R$ DNA was subcloned into the BamHI site of pAMPTs, creating pND10. pND10 contains a unique $X$ hol restriction site 20 codons downstream of the $5^{\prime}$ end of the $c p x R$ open reading frame. pND10 was digested with XhoI, the 3 ' overhangs were filled in with Klenow fragment (Sambrook et al. 1989), and the resulting fragment was ligated to the spectinomycin-resistance cassette described by Fellay et al. (1987). This subcloning created pND11. This $c p x R$ disruption was also recombined onto the chromosome as described (Hamilton et al. 1989|. The chromosomal disruptions of $c p x R$ and $c p \times A$ were confirmed by Southern hybridization. The insertion within the $c p \times R$ open reading frame is polar and strains containing this insertion are $c p x R^{-}$and $c p x A^{-}$. When a $c p x R$ null strain is complemented with plasmid pND10 (containing $c p x R$ ), the strain behaves as a $c p x A^{-}$strain in that $\operatorname{deg} P-l a c Z$ transcription is increased dramatically in the presence of carbon sources such as D-glucose /see Fig. 4 and Results, Acetyl-phosphate can stimulate $\operatorname{deg} P$ transcription through $C p \times R$ ).

\section{$\beta$-Galactosidase assays}

Cells were grown at $37^{\circ} \mathrm{C}$ overnight in Luria broth or M63 minimal medium supplemented with $0.4 \%$ of a given carbon source. Cells were then subcultured $\{1: 40\}$ into $2 \mathrm{ml}$ of the same medium and grown to mid-log phase at $30^{\circ} \mathrm{C}$ or $37^{\circ} \mathrm{C}$. $\beta$-Galactosidase activities were determined utilizing a microtiter plate assay (Slauch and Silhavy 1991) and are expressed as (U/ $\left.A_{600}\right) \times 10^{3}$, where units (U) equal micromoles of product formed per minute. A minimum of four independent assays were performed on each strain, and the results were averaged to obtain the indicated activities. Error bars indicate the standard devia- tion. The absence of error bars indicates that the standard deviation fell below the resolution limit of the graphing program.

Preparation of E. coli RNA, S1 nuclease protection assays, and DNA sequencing

RNA was prepared from strains grown at $30^{\circ} \mathrm{C}$ in Luria broth as described by Barry et al. (1980). A 340-nucleotide-long fragment, spanning from position 1 to 340 of the published $\operatorname{deg} P$ sequence (Lipinska et al. 1988), was used to create a radioactive probe for $\mathrm{S} l$ experiments. The probe was phosphorylated with $\left[{ }^{32} \mathrm{P}\right] \mathrm{ATP}$ in the forward reaction as described (Sambrook et al. 1989). Total RNA $(60 \mu \mathrm{g})$ was used in each Sl assay, and the assays were performed as described in Sambrook et al. (1989). The DNA sequence of $\operatorname{deg} P$ was determined as described previously (Russo et al. 1993). The $\operatorname{deg} P$ sequencing reactions and S1 nuclease samples were electrophoresed on $8 \%$ polyacrylamide sequencing gels and analyzed using the PhosphorImager ImageQuant (Molecular Dynamics) analysis program.

\section{Acknowledgments}

We are indebted to C. Gross, J. Mecsas, P. Rouviere, and A. de las Penas for providing unpublished materials for this study and for communicating results prior to publication. We also thank the Silhavy Laboratory, C. Gross, A. Ninfa, P. Rouviere and A. de las Peñas for helpful discussions. We also thank S. Clarke, U. Henning, J. Ichikawa, M. Inouye, R. Misra, A. Ninfa, R. Ogata, G. Phillips, M. Villarejo, and H. Wu for materials used in this study. This work was supported by National Institutes of Health (NIH) training grants awarded to P.N.D., W.B.S., and C.L.C. W.B.S. was also supported by a Princeton University Research Board Tuition Award. T.J.S. was supported by NIH grant GM34821.

The publication costs of this article were defrayed in part by payment of page charges. This article must therefore be hereby marked "advertisement" in accordance with 18 USC section 1734 solely to indicate this fact.

\section{References}

Barry, G., C. Squires, and C.L. Squires. 1980. Attenuation and processing of RNA from the rpl/L-rpoBC transcription unit of RNA polymerase. Proc. Natl. Acad. Sci. 77: 3331-3335.

Bukau, B. 1993. Regulation of the Escherichia coli heat-shock response. Mol. Microbiol. 9: 671-680.

Carlson, J.H. and T.J. Silhavy. 1993. Signal sequence processing is required for the assembly of LamB trimers in the outer membrane of Escherichia coli. I. Bacteriol. 175: 3327-3334.

Chen, R. and U. Henning. 1987. Nucleotide sequence of the gene for the peptidoglycan-associated lipoprotein of Escherichia coli K12. Eur. J. Biochem. 163: 73-77.

Craig, E.A., J. Kramer, J. Shilling, M. Werner-Washburne, S. Holmes, J. Kosic-Smithers, and C.M. Nicolet. 1989. SSC1, an essential member of the yeast HSP70 multigene family, encodes a mitochondrial protein. Mol. Cell Biol. 9: 3000-3008.

Craig, E.A., B.D. Gambill, and R.J. Nelson. 1993. Heat shock proteins: Molecular chaperones of protein biogenesis. Microbiol. Rev. 57: 402-414.

Deshaies, R.J., B.D. Koch, M. Werner-Washburne, E.A. Craig, and R. Schekman. 1988. A subfamily of stress proteins facilitates translocation of secretory and mitochondrial precursor polypeptides. Nature 332: 800-805.

Dong, J.S., S. Iuchi, H.S. Kwan, Z. Lu, and E.C.C. Lin. 1993. The deduced amino-acid sequence of the cloned $c p \times R$ gene sug- 
gests the protein is the cognate regulator for the membrane sensor, CpxA, in a two-component signal transduction system of Escherichia coli. Gene 136: 227-230.

Erickson, J.W. and C.A. Gross. 1989. Identification of the $\sigma^{\mathrm{E}}$ subunit of Escherichia coli RNA polymerase: A second alternate $\sigma$ factor involved in high-temperature gene expression. Genes \& Dev. 3: 1462-1471.

Fellay, R., J. Frey, and H. Krisch. 1987. Interposon mutagenesis of soil and water bacteria: A family of DNA fragments designed for in vitro insertional mutagenesis of Gram-negative bacteria. Gene 52: 147-154.

Gething, M.-J. and J. Sambrook. 1992. Protein folding in the cell. Nature 355: 33-45.

Goldberg, A.L. 1992. The mechanism and functions of ATPdependent proteases in bacterial and animal cells. Eur. $J$. Biochem. 203: 9-23.

Gottesman, S. 1989. Genetics of proteolysis in Escherichia coli. Annu. Rev. Genet. 23: 163-198.

Guzman, L., J.J. Barondess, and J. Beckwith. 1992. FtsL, an essential cytoplasmic membrane protein involved in cell division in Escherichia coli. J. Bacteriol. 174: 7717-7728.

Hamilton, C.M., A. Marti, B.K. Washburn, P. Babitzke, and S.R. Kushner. 1989. New method for generating deletions and gene replacements in Escherichia coli. I. Bacteriol. 171: 4617-4622.

Harris, D.C. 1987. Quantitative chemical analysis. W.H. Freeman and Company, New York.

Ichikawa, J.K., C. Li, J. Fu, and S. Clarke. 1994. A gene at 59 minutes on the Escherichia coli chromosome encodes a lipoprotein with unusual amino acid repeat sequences. I. Bacteriol. 176: 1630-1638.

Jung, J.U., C. Gutierrez, and M.R. Villarejo. 1989. Sequence of an osmotically inducible lipoprotein gene. $/$. Bacteriol. 171: $511-520$.

Lipinska, B., S. Sharma, and C. Georgopoulos. 1988. Sequence analysis and regulation of the htrA gene of Escherichia coli: A $\sigma^{32}$-independent mechanism of heat-inducible transcription. Nucleic Acids Res. 16: 10053-10067.

Lipinska, B., M. Zylicz, and C. Georgopoulos. 1990. The HtrA (DegP) protein, essential for Escherichia coli survival at high temperatures, is an endopeptidase. I. Bacteriol. 172: 17911797.

Lukat, G.S., W.R. McCleary, A.M. Stock, and J.B. Stock. 1992. Phosphorylation of bacterial response regulator proteins by low molecular weight phospho-donors. Proc. Natl. Acad. Sci. 89: 718-722.

McCleary, W.R., J.B. Stock, and A.J. Ninfa. 1993. Is acetyl phosphate a global signal in Escherichia coli? /. Bacteriol. 175: 2793-2798.

McEwen, J. and P.M. Silverman. 1980a. Chromosomal mutations of Escherichia coli $\mathrm{K}-12$ that alter the expression of conjugative plasmid function. Proc. Natl. Acad. Sci. 77: 513-517.

. 1980b. Mutations in genes $c p x A$ and $c p x B$ of Escherichia coli $\mathrm{K}-12$ cause a defect in isoleucine and valine synthesis. $J$. Bacteriol. 144: 68-73.

-1982. Mutations in genes $c p \times A$ and $c p \times B$ alter the protein composition of Escherichia coli inner and outer membranes. J. Bacteriol. 151: 1553-1559.

McEwen, J., L. Sambucetti, and P.M. Silverman. 1983. Synthesis of outer membrane proteins in $c p x A c p \times B$ mutants of Escherichia coli K-12. J. Bacteriol. 154: 375-382.

Mecsas, J., P.E. Rouviere, J.W. Erickson, T.J. Donohue, and C.A. Gross. 1993. The activity of $\sigma^{\mathrm{E}}$, an Escherichia coli heatinducible $\sigma$-factor, is modulated by expression of outer membrane proteins. Genes \& Dev. 7: 2618-2628.
Miller J.H. 1992. A short course in bacterial genetics: A laboratory manual and handbook for Escherichia coli and related bacteria. Cold Spring Harbor Laboratory Press, Cold Spring Harbor, New York.

Misra, R. and S.A. Benson. 1988. Genetic identification of the pore domain of the OmpC porin of Escherichia coli K-12. I. Bacteriol. 170: 3611-3617.

Misra, R. and P.R. Reeves. 1987. Role of micF in the tolC-mediated regulation of $\mathrm{OmpF}$, a major outer membrane protein of Escherichia coli K-12. I. Bacteriol. 169: 4722-4730.

Mori, K., W. Ma, M.-J. Gething, and J. Sambrook. 1993. A transmembrane protein with a cdc2 + CDC28-related kinase activity is required for signalling from the ER to the nucleus. Cell 74: 743-756.

Nakamura, K., Y. Masui, and M. Inouye. 1982. Use of a lac promoter-operator fragment as a transcriptional control switch for expression of the constitutive lpp gene in Escherichia coli. J. Mol. Appl. Genet. 1: 289-299.

Ogata, R.T., C. Winters, and R.P. Levine. 1982. Nucleotide sequence analysis of the complement resistance gene from plasmid R100. J. Bacteriol. 151: 819-827.

Parkinson, J.S. 1993. Signal transduction schemes of bacteria. Cell 73: 857-871.

Raina, S., D. Missiakas, and C. Georgopoulos. 1995. The rpoE gene encoding the $\sigma^{\mathrm{E}}\left(\sigma^{24}\right)$ heat shock factor of Escherichia coli. EMBO /. (in press).

Rainwater, S. and P.M. Silverman. 1990. The Cpx proteins of Escherichia coli K-12: Evidence that $c p x A$, ecfB, ssd, and eup mutations all identify the same gene. I. Bacteriol. 172: 2456-2461.

Rose, M.D., L.M. Misra, and J.P. Vogel. 1989. KAR2, a karyogamy gene, is the yeast homolog of the mammalian $\mathrm{BiP} /$ GRP78 gene. Cell 57: 1211-1221.

Rouviere, P.E., A. de las Peñas, J. Mecsas, C.Z. Lu, K.E. Rudd, and C.A. Gross. 1995. rpoE, the gene encoding the second heat-shock sigma factor, $\sigma^{\mathrm{E}}$, in Escherichia coli. EMBO I. (in press).

Russo, F., J.M. Slauch, and T.J. Silhavy. 1993. Mutations that affect separate functions of OmpR, the phosphorylated regulator of porin transcription in Escherichia coli. I. Mol. Biol. 231: $261-273$.

Sambrook, J., E.F. Fritsch, and T. Maniatis. 1989. Molecular cloning: a laboratory manual, 2nd ed. Cold Spring Harbor Laboratory Press, Cold Spring Harbor, New York.

Silhavy, T.J., M.L. Berman, and L.W. Enquist. 1984. Experiments with gene fusions, Cold Spring Harbor Laboratory, Cold Spring Harbor, New York.

Silverman, P.M., L. Tran, R. Harris, and H.M Gaudin. 1993. Accumulation of the F Plasmid TraJ Protein in $c p x$ mutants of Escherichia coli. J. Bacteriol. 175: 92-1-925.

Simons, R.W., F. Houman, and N. Kleckner. 1987. Improved single and multicopy lac-based cloning vectors for protein and operon fusion. Gene 53: 85-96.

Slauch, J.M. and T.J. Silhavy. 1991. cis-acting ompF mutations that result in OmpR-dependent constitutive expression. $/$. Bacteriol. 173: 4039-4048.

Slauch, J.M., S. Garrett, D.E. Jackson, and T.J. Silhavy. 1988. EnvZ functions through OmpR to control porin gene expression in Escherichia coli K-12. I. Bacteriol. 170: 439-441.

Snyder, W.B. and T.J. Silhavy. 1995. $\beta$-Galactosidase is inactivated by intermolecular disulfide bonds and is toxic when secreted to the periplasm of Escherichia coli. J. Bacteriol. 177: (in press).

Stock, J.B., A.M. Stock, and J.M. Mottonen. 1990. Signal transduction in bacteria. Nature 344: 395-400.

Stoker, N.G., N. F. Fairweather, and B.G. Spratt. 1982. Versatile 
Danese et al.

low-copy-number plasmid vectors for cloning in Escherichia coli. Gene 18: 335-341.

Strauch, K.L. and J. Beckwith. 1988. An Escherichia coli mutation preventing degradation of abnormal periplasmic proteins. Proc. Natl. Acad. Sci. 85: 1576-1580.

Strauch, K.L., K. Johnson, and J. Beckwith. 1989. Characterization of $\operatorname{deg} P$, a gene required for proteolysis in the cell envelope and essential for growth of Escherichia coli at high temperature. J. Bacteriol. 171: 2689-2696.

Wang, Q.P. and J.M. Kagnuni. 1989. A novel sigma-factor is involved in expression of the rpoH gene of Escherichia coli. J. Bacteriol. 171: 4248-4253.

Wanner, B.L. and M.R. Wilmes-Riesenberg. 1992. Involvement of phosphotransacetylase, acetate kinase, and acetyl phosphate synthesis in control of the phosphate regulon in Escherichia coli. J. Bacteriol. 174: 2124-2130.

Weber, R.F. and P.J. Silverman. 1988. The Cpx proteins of Escherichia coli K-12: Structure of the CpxA polypeptide as an inner membrane component. J. Mol. Biol. 203: 467-476.

Yu, F., S. Inouye, and M. Inouye. 1986. Lipoprotein-28, a cytoplasmic membrane lipoprotein from Escherichia coli. I. Biol. Chem. 261: 2284-2288.

Zeilstra-Ryalls, I., O. Fayet, and C. Georgopoulos. 1991. The universally conserved GroE (Hsp60) chaperonins. Annu. Rev. Microbiol. 45: 301-325. 


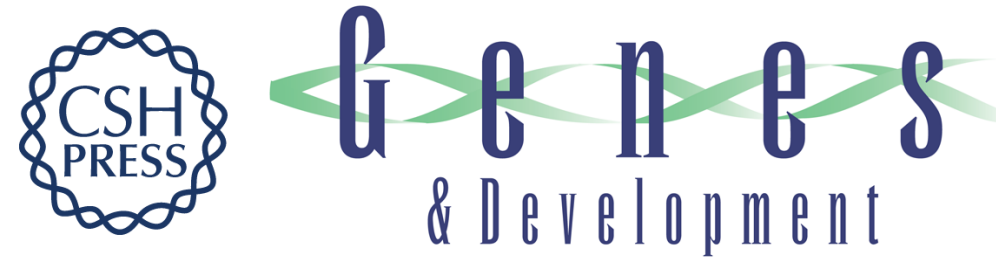

\section{The Cpx two-component signal transduction pathway of Escherichia coli regulates transcription of the gene specifying the stress-inducible periplasmic protease, DegP.}

P N Danese, W B Snyder, C L Cosma, et al.

Genes Dev. 1995, 9:

Access the most recent version at doi:10.1101/gad.9.4.387

References This article cites 47 articles, 28 of which can be accessed free at: http://genesdev.cshlp.org/content/9/4/387.full.html\#ref-list-1

License

Email Alerting Service

Receive free email alerts when new articles cite this article - sign up in the box at the top right corner of the article or click here.

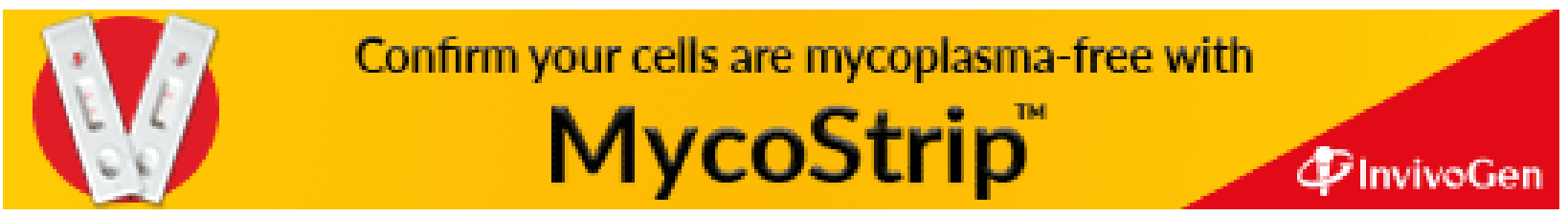

